\title{
Composite indicators as an innovative methodology for Communication Sciences: implementation for the assessment of European public service media
}

\author{
Olga Blasco-Blasco; Marta Rodríguez-Castro; Miguel Túñez-López
}

Nota: Este artículo se puede leer en español en:

http://www.elprofesionaldelainformacion.com/contenidos/2020/jul/blasco-rodriguez-tunez_es.pdf

How to cite this article:

Blasco-Blasco, Olga; Rodríguez-Castro, Marta; Túñez-López, Miguel (2020). “Composite indicators as an innovative methodology for Communication Sciences: implementation for the assessment of European public service media". Profesional de la información, v. 29, n. 4, e290437.

https://doi.org/10.3145/epi.2020.jul.37

Article received on 10 January 2020 Final acceptance: 15 March 2020
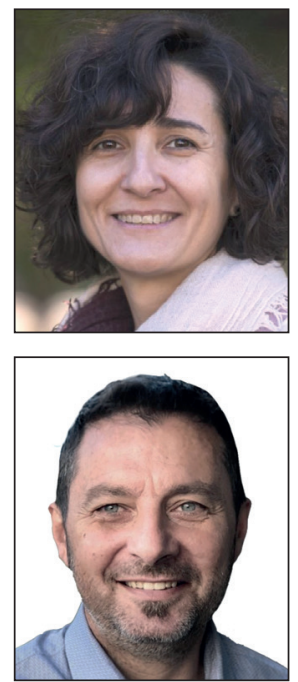

Olga Blasco-Blasco

https://orcid.org/0000-0001-8576-8526

Universitat de València

Facultad de Economía

Departamento de Economía Aplicada

Avda. dels Tarongers, $\mathrm{s} / \mathrm{n}$.

46021 Valencia, Spain

olga.blasco@uv.es

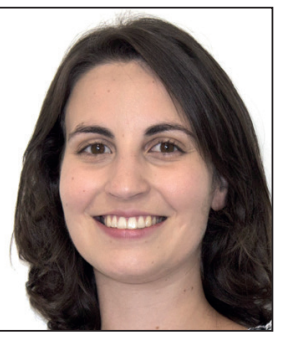

Marta Rodríguez-Castro $\square$

https://orcid.org/0000-0002-1399-9154

Universidade de Santiago de Compostela Facultad de Ciencias de la Comunicación Depto. de Ciencias de la Comunicación Avenida de Castelao, s/n. Campus Norte 15782 Santiago de Compostela, Spain m.rodriguez.castro@usc.es

\begin{abstract}
The currently dominant scientific production model in the field of Communication exhibits an excess of standardization towards mainly empirical work that is overwhelming caried out using quantitative techniques based on simple statistical analyses, in many cases limiting the presentation of results to a reading of the available data. This article presents an innovative proposal in this area, designed as a new form of dissemination and scientific presentation, with the objective of constructing three composite indicators that, when applied to European public service media, will enable the assessment of the perception of their social value, independence, and management efficiency. Another aim of the study is to provide a comparative vision of these three aspects in all the countries of the European Union except Malta and Luxembourg. This methodology is innovative because it explains the process in detail and justifies the validity of the documentary sources that were used to facilitate its replication or questioning, and reinforces the discussion of the results obtained by evaluating the robustness of the indicators created, before determining which was the most appropriate and comparing the results with a multicriteria decision analysis technique, the Topsis method (technique for order preference by similarity to ideal solution), proposed by Hwang and Yoon (1981). The results show that the synthetic indicators constitute an innovative, original, and validatable methodological tool that can contribute to the advancement of research in Communication.
\end{abstract}

\section{Keywords}

Public service media; Research; Research methods; Communication; Composite indicators; Social value; Independence; Management; Innovation; Efficiency; TV; Television. 
Funding

This study is part of the activities of the research project (RTI2018-096065-B-I00) from the Programa Estatal de España de I+D+I addressed to Retos de la Sociedad of Ministerio de Ciencia, Innovación y Universidades (MCIU), the Agencia Estatal de Investigación (AEI), and the Fondo Europeo de Desarrollo Regional (Feder) on "New values, governance, financing, and public service media for the Internet society: European and Spanish contrasts."

\section{Introduction}

\subsection{Composite indicators in Communication}

Research in the area of Communication in Spain has experienced an "incidental improvement in methodological quality" in recent years, but with a

"tendency to publish empirical research (more than $90 \%$ of published articles), and specifically of a quantitative nature, with a clear predominance of content analysis as a data acquisition technique" (Martínez-Nicolás; Saperas-Lapiedra, 2016, p. 1381).

However, such quantitative results are usually mainly addressed using simple statistical analysis. The contributions of Caffarel-Serra, Ortega-Mohedano and Gaitán-Moya (2017); Gaitán-Moya et al. (2018); Arcila-Calderón, Piñuel-Raigada, and Calderín-Cruz (2013); Fernández-Quijada and Masip (2013); López-Rabadán and Vicente-Mariño (2011); Repiso, Delgado-López-Cózar, and Torres-Salinas (2011); Blázquez-Ochando (2015) and, among others, Túñez-López, Martínez-Solana and Valarezo-González (2014) are significant to provide a snapshot of the Communication area, observing a dominant scientific production model characterized by an excess of standardization of research in the field (Goyanes, 2017).

No studies presenting an analysis of the statistical tools and approaches used can be found, although it can be inferred from the cited studied that it is infrequent to resort to the design and elaboration of composite indicators as a research method. The complexity of their elaboration and the need for solid previous references seem to be deterrents when planning an investigative approach in Communication, despite the fact that composite indicators:

i) are adjusted to the specific problem investigated in each case

ii) allow new perspectives to emerge by relating variables

iii) normalize results and facilitate comparative stages compared with the fragmented reading of simple statistics

iv) promote the uniqueness of the results

v) if validated, contribute to strengthening the area because they provide new tools

vi) can be used as a key performance indicator for management, in both Communication and other disciplines.

As a new form of scientific dissemination and presentation in the field, the aim of the current study is to construct three composite indicators to address specific aspects of public service media as a subarea of Communication of general interest and social importance and, furthermore, to validate their relevance and results. This article thus presents three indicators (of social value, of independence, and of efficiency) whose results enable an ordering and comparison of all the countries of the European Union except Malta and Luxembourg ${ }^{1}$.

These indicators have been constructed based on a combination and interrelation of variables from secondary sources, including audience data from the different public broadcasters analyzed, data related to their budgets (both public and commercial), the results of the Media Pluralism Monitor and Special Eurobarometer 452 to measure the level of independence of the public service media in each country, the Democracy Index prepared by The Economist, and the Corruption Perception Index prepared by Transparency International.

The efficiency indicator of mixed financing (Indefimix) of European public service media, defined in Blasco-Blasco, Campos-Freire, and Juanatey-Boga (2017), is taken as a reference, using the following variables: Public Revenue divided by the Gross Domestic Product of each country, Other Income, and Audience. This indicator evaluates the efficiency of commercial financing, considering the allocation of public funds from all the countries of the European Union except Luxembourg and Malta ${ }^{1}$. Secondly, the perception of citizens regarding the independence of public broadcasting is incorporated, revealing a fall by one-third in countries such as France and Spain, while Lithuania became among the best managed (Graph 1).

\subsection{The methodological challenge of research on public service media}

Analysis and evaluation of public service media (PSMs) have been and remain a constant issue for both national organizations, such as the regulatory authorities in the Communication sector established in each state (Ofcom, 2019), or even 


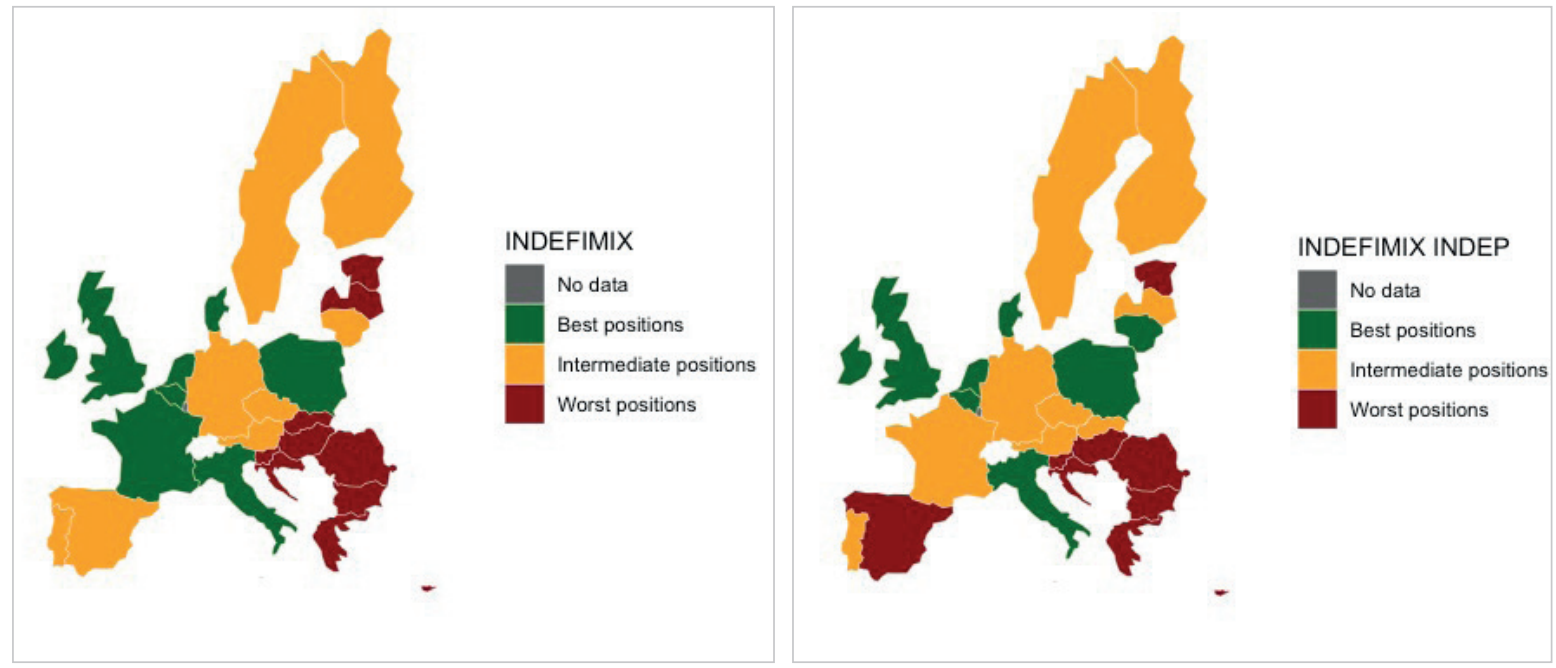

Graph 1. Mixed financing indicators (Indefimix): (a) without and (b) with the inclusion of independence.

public broadcasters themselves; as well as for supranational entities, such as Unesco (Mendel, 2011) or the Council of Europe (2009), among others. The diverse and heterogeneous nature of public communication systems, even in Europe, has made the design of comparative research an ever-changing challenge.

This complex and changing context poses a challenge not only for PSMs but also for researchers and organizations that study public service media. Publications in the research subarea of Communication have mainly been based on the application of quantitative methods and descriptive approaches, an effect that is especially notable in research produced in Spain. Casado-Del-Río and Fernández-Quijada (2015, p. 74), for example, detect a "methodological deficiency" in research on communication policies published by Spanish academics between 2002 and 2011, highlighting document analysis as the main method. More recent studies confirm that this deficiency, while still present, is being corrected as Spanish academics expand their methodological resources towards techniques such as content analysis, which endow scientific productions with a more empirical nature (Goyanes; Rodríguez-Gómez; Rosique-Cedillo, 2018).

At an international level, the challenge of developing comparative research between public service media also limits knowledge on public broadcasting and the proposal of new strategies and solutions applicable in the current media context described above. The complexity characterizing this area means that there is still no standardized method for its analysis (Raats; Pauwels, 2011).

However, in recent years, studies that aspire to evaluate the performance of public service media in a comparative way by applying statistical measures (Norris, 2009), quantitative techniques (Brüggemann et al., 2014), and qualitative techniques based on fuzzy logic (Downey; Stanyer, 2010; 2013; Büchel et al., 2016) have been carried out, albeit all exhibiting methodological complexity. In Spain, for example, the Indicator of social profitability in communication (Irscom) developed by Chaparro, Olmedo, and Gabilondo (2016) stands out, allowing the evaluation of the functioning of communication media based on criteria linked to public interest, such as citizen participation or transparency levels.

At an international level, one of the most recent and relevant pieces of research is that published by Saurwein, Eberwein, and Karmasin (2019), who investigated the relationship that can be established between the funding of 17 public European media and their audiences, considering both audience share data of an eminently quantitative nature, and the confidence of citizens in the independence of public service media with respect to external pressures and their use as an information source. Based on the interrelation of data obtained from different secondary sources, those authors propose an analytical system that they believe can contribute to

"bringing objectivity to current debates on political and managerial issues such as the television license fee"

(Saurwein; Eberwein; Karmasin, 2019, p. 2).

This type of more complex study can enable a great step forwards in Communication research. In this article, it will be argued that the construction and application of synthetic indicators can provide an innovative and useful methodology for designing original research aimed at the objectives described above and with normalized results that enable a more well-structured and knowledgeable comparison between systems..

\subsection{Current problems with public service media as an object of study}

The media sector is affected by a process of continuous transformation that in recent years has been marked by the emergence of digital platforms that have led to the disruption of the business models of traditional media (Campos-Freire; De-Aguilera-Moyano; Rodríguez-Castro, 2018; Miguel-De-Bustos; Izquierdo-Castillo, 2019) with the consequent modification of consumer habits (Nelson; Lei, 2018). 
Against this background, European public service media are struggling to develop strategies that allow them to maintain the legitimacy of their public service mission (Trappel, 2016), establish and root their activity in the digital ecosystem, and define their relationship with digital platforms (Rotermund, 2018). However, this task is not proving easy, due to a series of extrinsic factors that apply pressure on European public broadcasters, among which one can highlight changes in financing models, political pressures, and audience migration.

Changes in media consumption habits have greatly impacted the legitimacy of what was the most widespread means of financing among European public service media until a few years ago, the television license, based on the payment of a fee linked to possession of a television in each home (Berg; Lund, 2012; Lowe; Berg, 2013). In a system where the consumption of content via public radio and television no longer requires a television set and is increasingly individual, it became necessary to update the public revenue channels of these media so that their financing models do not become obsolete and will correspond to the reality of consumption by citizens (Ala-Fossi, 2012).

Therefore, over the past decade, there have been numerous cases of countries that have modified the financing models of their public broadcasting stations, a complex and risky decision that, on many occasions, is usually accompanied by a decrease in the budgets of public service media (Warner, 2019). In Denmark, for example, the announcement of the replacement of the television license fee by a public service tax was accompanied by a series of cuts to $D R$, reducing both its budget and services (Public Media Alliance, 2019). Through this change, this Scandinavian country aligned itself with a trend started by Iceland in 2009 and later repeated by Finland (2013), Sweden (2019), and Norway (2020). Beyond the Nordic region, Germany has also modified the financing system of the $A R D$ and ZDF, which since 2013 has been based on a household tax unrelated to television ownership (Ramsey; Herzog, 2018), and the demands of Ireland to adjust RTÉ's financing to new forms of consumption to avoid the reduction of its budget derived from the decrease in televisions in the country, as well as from high rates of evasion (Ramsey, 2018).

This context of reforms affecting the financing of public service media has been marked by another European trend: an increase in the pressure exerted from the political environment, especially from far-right parties. The most visibly representative event of the questioning of the financing of public service media (in this case SRR-SRG) took place in Switzerland when a referendum was held on the abolition of the television license fee. The "No Billag" (No License Fee) campaign, initiated by a group of young people linked to the Radical Liberal Party (FDP) and the Central Democratic Union (SVP/UDC) who were reluctant to pay for a service they no longer used (Mombelli, 2018), finally concluded with strong popular support for Swiss public service media funding. In Germany, constant attacks have been launched by the far-right Alternative für Deutschland party against the public funding systems of the $A R D$ and $Z D F$, adding to the $44 \%$ of Germans who consider the fee to be too high (Inhoffen, 2018). In Spain, Radiotelevisión Española and the public service media of the autonomous communities have also been criticized by the far-right party Vox, which advocated first for their closure and later for their privatization (González, 2019). The most paradigmatic public radio/television service, the $B B C$, has not been without its problems either. Its governance structure is going through a crisis that led to the resignation of its CEO, Tony Hall, due to the growing hostility expressed by Boris Johnson's government towards the public corporation (Harrison; Wood, 2020).

On the other hand, the poor state of health of the independence of funding and governance with respect to political powers in some countries has been highlighted by the results of the Media Pluralism Monitor (Center for Media Pluralism and Media Freedom, 2017). According to the latest report available, from 2017, countries such as Hungary, Poland, Bulgaria, Croatia, Finland, and Italy do not sufficiently protect the governance and funding structures of their public service media, leaving them at a high risk of being susceptible to political pressure, an alarming situation within the context of the European Union.

Efficiency indicators fit the requirements of public service media (PSMs), which need to identify strategies to allow them to recover or consolidate their legitimacy before the public. To do this, they must face the significant decreases in audience that they have experienced in recent years, since audience data remain one of the fundamental indicators when assessing the trust that citizens place in public service media (Rodríguez-Vázquez; Direito-Rebollal, 2018). This decrease is especially critical if one focuses on young audiences, who, in an environment of increasing competition, are turning less and less to the offering of public service media (Lowe; Maijanen, 2019; Schulz; Levy; Nielsen, 2019).

\section{Composite indicators: how are they prepared, and what are they for?}

Some countries use quality indicators to measure the impact of and satisfaction with their broadcasting service. With the development of big data, the public service media sector is seeking new strategies to evaluate aspects such as social impact (Campos-Freire; Soengas-Pérez; Rodríguez-Castro, 2018). One way to do this is through the development of composite indicators, since they can summarize complex realities in a way that is easier to interpret than a battery of individual indicators, but without information loss. They are a useful tool for policy analysis, communication, and public debate, as well as being a management instrument that helps decision-makers (Saisana; Tarantola, 2002; OECD, 2008), permitting the identification of common trends by combining several simple indicators, drawing attention to particular 
issues, as well as comparing performance and evolution in various countries (Saltelli, 2007). However, one must be cautious when preparing such indicators because, if poorly constructed, they can convey erroneous messages or interpretations, give rise to inappropriate policies if performance dimensions (which can sometimes be difficult to measure) are ignored, and cause decision-makers to draw simplistic or incorrect conclusions (Saisana; Tarantola, 2002; Nardo et al., 2005; OECD, 2008). In fact, composite indicators should be considered as the first step in initiating a debate and stimulating the affected interest groups (OECD, 2008).

To build a good composite indicator measuring multidimensional concepts that cannot be captured by a simple indicator, assumptions, stages, and procedures must be established to enable a verification of its validity based on a conceptual framework that faithfully reflects what one wishes to measure. As the procedure is similar to mathematical models, subjective judgments are needed to help decide which individual indicators or variables to include, their assessment, and normalization and combination methods accepted by experts. Following the method developed by the OECD in the Handbook on Constructing Composite Indicators (OECD, 2008), in this work we study aspects such as:

- Selection of variables or partial indicators:

To construct a good indicator, it is important to study which variables to include carefully, as well as to analyze their relevance and the relationships between them. To achieve this, the theoretical framework and suggestions from experts and stakeholders must be taken into account.

- Normalization:

The units and range in which the indicators are measured must be comparable. If the variables are expressed in incompatible units, it is advisable to normalize the original data so that all the variables take values within the range [0, 1] and are comparable.

- Choice of weightings:

The importance of each variable in the indicator is studied by taking into account the theoretical framework, then based on previous studies or expert judgment, the weight of each can be determined.

- Combination method:

Indicators should be combined by taking account of the theoretical framework. At this point, it is important to consider whether the objective is to maximize or minimize the value of each partial indicator. The country with the best combination of resources is considered to be that with the highest value.

\section{Methodology for the design of indicators for European public televisions}

\subsection{Selection of data and variables}

In the development of the efficiency indicator, considering different scenarios, the following variables and partial indicators for the year 2016 are considered:

The Daily share (DSH) of European Public Service Media (PSM). The audience of public televisions in each country (Eurodata, 2016; EAO, 2016) is measured as a percentage in the range $[0,100]$, such that, the higher the value, the larger the television audience.

The Media Pluralism Monitor (MPM) from the Center for Media Pluralism and Media Freedom (2017) is an indicator of perception regarding the governance of $P S M$ that measures the risk regarding the independence of governance and financing of PSMs, evaluated based on a set of 20 indicators covering four areas:

- Basic protection

- Market plurality

- Political independence

- Social inclusion

The indicators cover legal, economic, and sociopolitical issues related to political, cultural, geographical, structural, and content aspects. The indicator lies in the range $[0,100]$. The higher this percentage, the greater the threat identified by this variable, while the closer it is to zero, the lower the risk.

Independence (IND) will be measured by the PSM's pluralism perception indicator, based on the Special Eurobarometer 452 (European Commission, 2016). The information was obtained from a survey of 27,000 EU citizens. The data reflect the percentage of people who answered affirmatively to the question: Is the public service media free from political pressure? Thus, independence takes values in the range $[0,100]$, and the higher the value of the indicator, the greater the independence.

The Democracy Index $(D I)$ is a quality indicator, designed by the intelligence unit of The Economist by adding 60 simple indicators measuring levels of democracy (The Economist, 2017), grouped into five categories: electoral processes and 
pluralism, civil liberties, functioning of the government, political participation, and political culture. This index is based on expert assessment collected through a questionnaire with a dichotomous (yes $=1$, no $=0$ ) or three-point scoring systems (in which the score 0.5 is added). This methodology is complemented by data on electoral participation and public opinion polls. The $D I$ results, presented on a scale between 0 and 10 , allow the analyzed countries to be classified into four categories: full democracies (8-10 points), imperfect democracies (6-7.9 points), hybrid regimes (4-5.9 points), and authoritarian regimes (<4 points).

The corruption perception indicator (CPI) is prepared by Transparency International (2017) to measure the perception of corruption in the public sector, being developed by the combination of data obtained from external sources, from a trustworthy institution, obtained using a solid methodology, and related to corruption in the public sector and allowing national and temporal comparisons. The data used for the construction of the indicator are standardized on a scale between 0 and 100, where 0 is the highest level of perceived corruption and 100 is the lowest.

The indicator of global financing budgets of the European PSM 2016. In this work, the percentage of the budget of public television corporations per capita will be used, that is, the budget per capita divided by the income or GDP per capita. In this way, the budget's share of total GDP is considered. The budget per capita allocated to television has been obtained from the Yearbook of the European Audiovisual Observatory $(E A O, 2016)$ and the Mavise database.

http://mavise.obs.coe.int

As it is measured as a percentage, it takes values in the range $[0,100]$, where the lower the value, the lower the percentage of gross domestic product dedicated to public television.

\subsection{Data normalization}

In the description of the variables, it was observed that they take different values, thus we proceed to normalize and limit the values to the range between 0 and 1. The normalization method used is Min-Max, since there are no negative values or extreme values that could distort the results of the indicator. Normalization is thus achieved by subtracting the minimum value divided by the range from each value of the variable for each country (), or the maximum minus the value of the variable divided by the range of the variable for each country (), depending on whether the criterion is maximization or minimization:

$$
\begin{aligned}
& \bar{x}_{i j}=\frac{x_{i j}-x_{\min }}{x_{\max }-x_{\min }}, i=1, \ldots, n, j=1, \ldots, m \\
& \bar{y}_{i j}=\frac{y_{\max }-y_{i j}}{y_{\max }-y_{\min }}, i=1, \ldots, n, j=1, \ldots, m
\end{aligned}
$$

\subsection{Weightings}

It may occur that some variables or partial indicators will have greater relative importance than others when performing the analysis, according to expert judgment. In addition, the correlation between the variables or simple indicators and how to compensate for this must be considered when preparing the indicator. Therefore, we assign a weight $w_{j}$ for each variable, such that:

$$
W=\left[w_{1}, w_{2}, \ldots, w_{m}\right] ; \quad 0 \leq w_{j} \leq 1 ; \sum_{j=1}^{m} w_{j}=1
$$

\subsection{Combination}

The proposed indicator is defined as the sum of the $r$ variables that we want to maximize (higher value is better), multiplied by the weight, plus the sum of the $(m-r)$ variables that we want to minimize (lower value is better), multiplied by the corresponding weight.

$$
I_{i j}=\sum_{j=1}^{r} w_{j} \bar{x}_{i j}+\sum_{j=r+1}^{m} w_{j} \bar{y}_{i j}
$$

The resulting indicator will take values between 0 and 1 . The higher the value of the indicator, the better the combination of variables.

\subsection{Country grouping}

Once the indicator scores have been obtained, each country can be ordered from highest to lowest and grouped into three categories according to tertiles as follows:

(a) those obtaining a higher score, being considered to be the best managed,

(b) those occupying an intermediate position, which are supposed to carry out normal management, and

(c) the worst-positioned ones, being interpreted as worse management of public service media financing (Blasco-Blasco et al., 2017). 


\section{Results of the application of the indicator under different scenarios}

The construction of the indicators must establish which variables to consider, how to combine them, and what weights to assign to each and study the possible conceptual scenarios to jointly analyze aspects such as audience, independence, governance, financing of public service media, and commercial income.

The first question to study is the effect of the budgets of public televisions, and the second is to assess whether one should include the rates of democracy and perception of corruption, since these refer to the situation of the country and are also variables that show a high degree of correlation.

In this section, three composite indicators are prepared that help us to order and classify the countries.

\subsection{Social value indicator}

To capture the social assessment of public TV in EU countries, we analyzed the Audience (DSH), Media Pluralism Monitor (MPM), Independence (IND), Democracy Index (DI), and Corruption Perception Index (CPI), taking into account that all these except MPM and CPI should be maximized.

Despite the correlation between $D I$ and $C P I$, we believe that it is important to consider the aspects they analyze. To avoid these variables becoming oversized and thus conditioning the result of the indicator, the experts assigned a lower weight to each of them. The weights proposed according to expert judgment were $0.3,0.17,0.2167,0.1334$, and 0.18 .

The grouping obtained by tertiles reveals that the countries in which citizens perceive a higher social value of public television are Germany, Austria, Belgium, Denmark, Finland, Ireland, the Netherlands, the United Kingdom, and Sweden. The countries with an intermediate rating are Croatia, Slovakia, Estonia, France, Italy, Lithuania, Portugal, and the Czech Republic. The countries in which citizens have the worst opinion regarding the social value of public television are Bulgaria, Cyprus, Spain, Slovenia, Greece, Hungary, Latvia, Poland, and Romania (Graph 2).

\subsection{PSM independence indicator}

To prepare the indicator of independence of the public service media, the variables Audience (DSH), Media Pluralism Monitor (MPM), and Independence (IND) are used and the budget for public television is incorporated. The public budget is considered to have an inverse relationship with the audience of public televisions. For this reason, we construct a new variable, the Corrected Audience (DSHCOR), obtained as the audience $(D S H)$ divided by $\alpha_{i}$, where $\alpha_{i}$ is the fraction or percentage (if multiplied by 100) of the public budget dedicated to public television per capita (PBUBPC) divided by the total budget for financing public TV (TBUGPC), that is, the total financing generated by public funds.

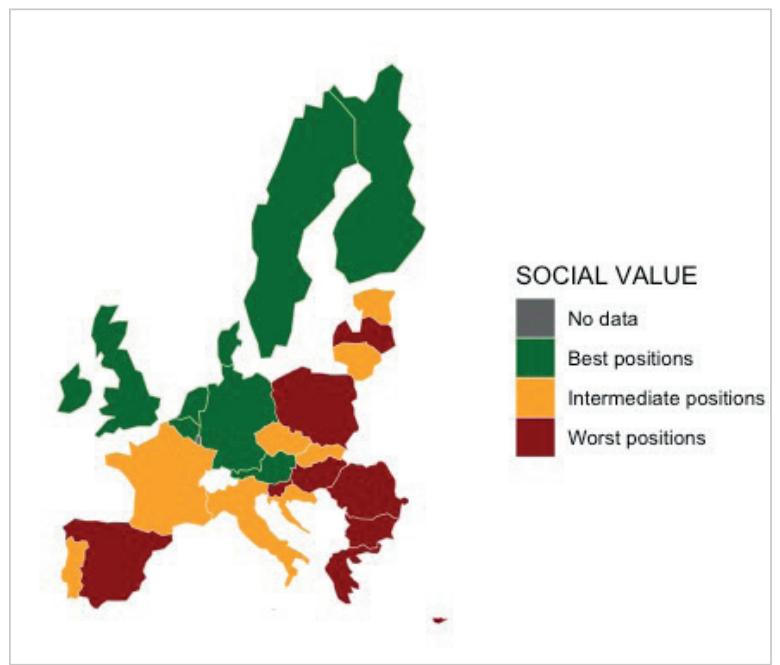

Graph 2. Social value indicator

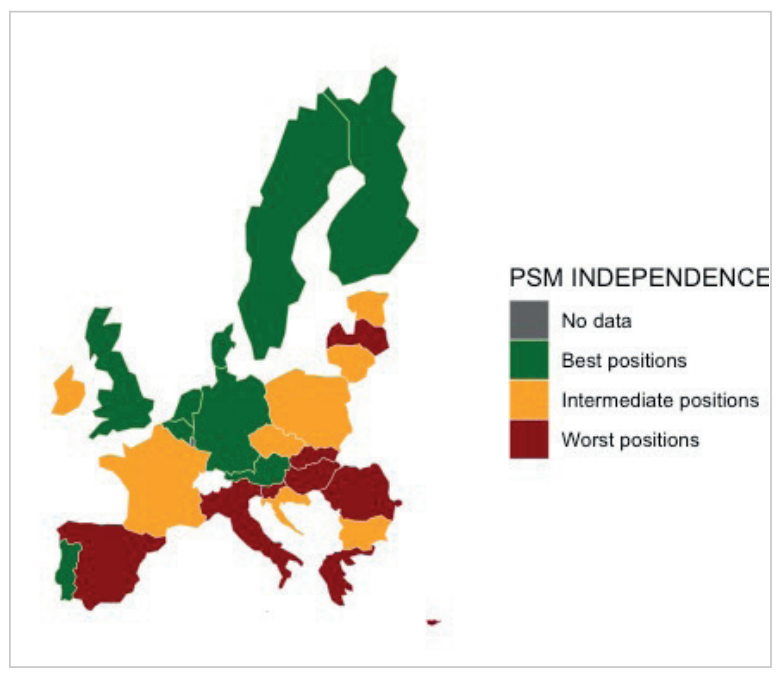

Graph 3. PSM independence indicator

$$
\text { DSHCOR }=\frac{1}{\alpha_{i}} D S H ; \text { donde } \alpha_{i}=\frac{\text { PBUGpc }}{\text { TBUGpC }}
$$

In the calculation of this indicator, the variable $D S H$ is replaced by the new variable $D S H C O R$, the data are normalized using expression (1), the weights $0.3,0.35$, and 0.35 are used, and the indicator is calculated using expression (3). Considering the grouping by tertiles of the PSM independence indicator, the grouping of the countries is as follows (Graph 3):

- Group with the best ratings: Germany, Austria, Belgium, Denmark, Finland, the Netherlands, Portugal, the United Kingdom, and Sweden.

- Group with intermediate valuations: Bulgaria, Croatia, Estonia, France, Ireland, Lithuania, Poland, and the Czech Republic.

- Group with the worst ratings: Cyprus, Slovakia, Slovenia, Spain, Greece, Hungary, Italy, Latvia, and Romania. 


\subsection{Efficiency indicator}

To elaborate the efficiency indicator, the Corrected Audience with the public budgets (DSHCOR), the MPM, and the IND are considered, while to address the perception of citizens about the political situation in their country and how it influences the financing and about the public television, the $D I$ and $C P I$ are also incorporated.

To elaborate this indicator, calculated using expression (3), it is normalized using expression (1) with the weights assigned by the expert assessment for the social value indicator $(0.3,0.17,0.2167,0.1334,0.18$, and 0.18$)$.

The classification of the countries into three groups offers the following results (Graph 4):

- The top-scoring countries are Germany, Austria, Belgium, Denmark, Finland, Ireland, the Netherlands, the United Kingdom, and Sweden.

- The countries that occupy an intermediate position are Slovakia, Estonia, France, Italy, Lithuania, Poland, Portugal, and the Czech Republic.

- The countries with the lowest scores are Bulgaria, Cyprus, Croatia, Slovenia, Spain, Greece, Hungary, Latvia, and Romania.

\section{Evaluation of the robustness of the indicator}

In the previous section, different scenarios were studied, before determining which is the most appropriate indicator in this case. Next, to determine the robustness of the indicator, the results will be compared with a multicriteria decision analysis technique, the Topsis method (Technique for order preference by similarity to ideal solution), proposed by Hwang and Yoon (1981). The objective of this method is to order alternatives, in our case countries, such that they are as close as possible to a positive ideal and as far as possible from a negative ideal. In the development of the Topsis method, which consists of seven steps (García-Cascales; Lamata, 2012; Lamata; Liern; Pérez-Gladish, 2016), aspects such as the normalization and weighting of the variables included in the model are considered, and the calculation of the distances to the positive and negative ideal enables the relative proximity to the ideal solution to be obtained and used to order the alternatives.

On applying the Topsis method to the variables considered in each indicator, using the same normalization and weights as applied in the construction of the indicator, and grouping the results by tertiles, the same grouping of countries is obtained as in the results of the indicators proposed herein.

Although this robustness assessment does not provide a sufficient guarantee for a reasonable composition of the indicator $(O E C D, 2008)$, the proposal of a solid theoretical framework and analysis of various scenarios support the robustness and coherence of the indicator constructed in this work.

\section{Discussion and conclusions}

Comparing the country rankings obtained using each indicator, it can be observed that, in general terms, the groupings are very similar. For the best-valued group, the social value and efficiency indicators show the same grouping, and when comparing these with the PSM independence indicator, only Portugal is considered as a country in an excellent position, to the detriment of Ireland. Five countries shift from the intermediate group to the worst positioned according to the indicator considered: Croatia, Bulgaria, Poland, Italy, and Slovakia. The intermediate group of the social value and independence indicators includes Croatia, while according to the efficiency indicator it lies in the worst-positioned group. Bulgaria is included in the worst-positioned group according to the social value and efficiency indicators, yet when applying the PSM independence indicator, it appears in the second group. Poland appears in the worst-positioned group according to the social value indicator but moves to the intermediate group when applying the indicators that consider the public budget (independence and efficiency indicators). Italy and Slovakia, on the other hand, are in the group of the worst-positioned countries according to the PSM independence indicator but move up to the intermediate group when applying the social value and efficiency indicators.

The results obtained using all three indicators, in particular the efficiency indicator, are reminiscent, albeit with nuances, of the categorization of media systems carried out by Hallin and Mancini (2004). The countries included in the corporate democratic system (Nordic countries, Germany, Belgium, the Netherlands, etc.) as well as those with liberal systems (the United Kingdom and Ireland) are included within the best-positioned group according to the three indicators applied 
in this article. On the contrary, the Southern European countries, linked to the polarized pluralist model, obtain the worst results. Central and Eastern European countries, which were not included in the original study by Hallin and Mancini but have been studied according to the same parameters by other researchers (Rantanen, 2013), also lie in intermediate or low positions.
Synthetic indicators constitute an innovative, original, and validatable methodological tool that can contribute to the advancement of research in Communication

These parallels are especially significant given the description in Hallin and Mancini's (2004) work on the public service media. While in the polarized pluralist model and the Central and Eastern Europe model, the political influence on public radio/television is notable, in the Democratic Corporatist model and, above all, the liberal model, a marked distance between the two spheres has been sought to improve the democratic functioning of the public service media.

In our proposal, the indicators presented allow us to observe that the best-ranked countries are those that adequately manage the budget of public televisions and in which citizens perceive a low level of corruption with independent television management. However, the worst positioned are mostly Eastern European countries, Greece, and Spain, where citizen perception of the independence of televisions and the country's situation in terms of corruption and the level of democracy of institutions is very low.

These results may open the door to future research that delves into the reasons that lead to certain countries being better positioned than others and, starting from a lesson-learning perspective, develop strategies aimed at improving the efficiency of public communication media.

The process of elaborating the three indicators presented herein, as well as their results, provide an example of the advantages brought about by the design of synthetic indicators and their application in the scientific field of Communication. The relationship established between different variables through this type of indicator allows researchers (as well as political agents or pressure groups) to obtain richer and more complex results than can be obtained from reading simple statistics, thereby advancing knowledge about the analyzed topic.

The combination of variables suggested herein to configure the indicators distinguishes them from others that already exist by connecting issues such as the democracy index or corruption perception index, which until now have not been studied in relation to the operation of public service media. This opens a new avenue for interdisciplinary research or other objects of study by allowing the design of synthetic indicators to expand the related variables, always starting from expert judgment.

Finally, one limitation that restricts the application of the three indicators presented herein should be indicated: the dependence on secondary sources. To construct the indicators of social value, independence, and efficiency, data from secondary sources were added, which was necessary considering that the data related to each variable must be obtained in a coordinated fashion and using common criteria in each country in order to be comparable and not distort the results of the indicator. Thus, for example, the use of data from the Special Eurobarometer 452 in 2016 constrains that the rest of the data obtained from other sources must also correspond to 2016, even when in some cases more recent data have already been published. In addition, resorting to databases such as Eurodata to obtain the audience percentage limits the real information that can be obtained, since it does not consider the audience of payment platforms with the development of the Internet or new modes of television consumption through mobile devices. Therefore, the interpretations derived from these data sources must be treated with caution.

However, despite this limitation, which could be overcome by identifying other available sources or (when allowed by the scope of the research) carrying out direct data collection, synthetic indicators can constitute an innovative, original, and validatable methodological tool that can contribute to the advancement of Communication research.
Communication research is usually limited to reading basic statistics. Composite indicators can motivate more complex studies that therefore advance knowledge in this field

\section{References}

Ala-Fossi, Marko (2012). "Social obsolescence of the TV fee and the financial crisis of Finnish public service media". Journal of media business studies, v. 9, n. 1, pp. 33-54.

https://doi.org/10.1080/16522354.2012.11073535

Arcila-Calderón, Carlos; Piñuel-Raigada, José-Luis; Calderín-Cruz, Mabel (2013). “La e-investigación de la comunicación: actitudes, herramientas y prácticas en investigadores iberoamericanos". Comunicar, v. 20, n. 40, pp. 111-118. https://doi.org/10.3916/C40-2013-03-01

Berg, Christian E.; Lund, Anker-Brink (2012). "Financing public service broadcasting: A comparative perspective". Journal of media business studies, v. 9, n. 1, pp. 7-22.

https://doi.org/10.1080/16522354.2012.11073533 
Blasco-Blasco, Olga; Campos-Freire, Francisco; Juanatey-Boga, Óscar (2017). “Una propuesta de indicador para medir la eficiencia de la financiación mixta de las radiotelevisiones públicas europeas”. Rect@, v. 18, n. 1, pp. 17-36. https://doi.org/10.24309/recta.2017.18.1.02

Blázquez-Ochando, Manuel (2015). "Tesis doctorales en las universidades españolas durante el período 1977-2014". mblazquez.es. Investigación en documentación, 23 noviembre.

https://mblazquez.es/tesis-doctorales-en-las-universidades-espanolas-durante-el-periodo-1977-2014

Brüggemann, Michael; Engesser, Sven; Büchel, Florin; Humprecht, Edda; Castro-Herrero, Laia (2014). „Hallin and Mancini revisited: Four empirical types of western media systems”. Journal of communication, v. 64, n. 6, pp. $1037-1065$.

https://doi.org/10.1111/jcom.12127

Büchel, Florin; Humprecht, Edda; Castro-Herrero, Laia; Engesser, Sven; Brüggemann, Michael (2016). “Building empirical typologies with QCA: Toward a classification of media systems”. The international journal of press/politics, v. 21, n. 2, pp. $209-232$. https://doi.org/10.1177/1940161215626567

Caffarel-Serra, Carmen; Ortega-Mohedano, Félix; Gaitán-Moya, Juan-Antonio (2017). “Investigación en Comunicación en la universidad española en el período 2007-2014". El profesional de la información, v. 26, n. 2, pp. 218-227. https://doi.org/10.3145/epi.2017.mar.08

Campos-Freire, Francisco; De-Aguilera-Moyano, Miguel; Rodríguez-Castro, Marta (2018). “Impacto de las plataformas globales en la competencia mediática y los resultados de las empresas de comunicación europeas". Comunicación y sociedad, v. 31, n. 3, pp. 223-240.

http://hdl.handle.net/10171/55792

Campos-Freire, Francisco; Soengas-Pérez, Xosé; Rodríguez-Castro, Marta (2018). “Indicadores de evaluación de los servicios informativos de la radiotelevisión pública”. El profesional de la información, v. 27, n. 2, pp. $267-277$. https://doi.org/10.3145/epi.2018.mar.05

Casado-Del-Río, Miguel-Ángel; Fernández-Quijada, David (2015). “References in communication policy research: a bibliographical characterization of articles published by Spanish authors". Communication \& society, v. 28, n. 2.

https://doi.org/10.15581/003.28.2.73-85

Center for Media Pluralism and Media Freedom (2017). Monitoring media pluralism in Europe: Application of the media pluralism monitor 2016 in the European Union, Montenegro and Turkey. 2017 Policy report. Florencia: European University Institute. ISBN: 9789290844594

https://cadmus.eui.eu/bitstream/handle/1814/46786/CMPF-MPM_PolicyReport2017.pdf

Chaparro, Manuel; Olmedo, Silvia; Gabilondo, Victoria (2016). “El Indicador de la Rentabilidad Social en Comunicación (IRSCOM): medir para transformar". Cuadernos de información y comunicación, v. 21, pp. 47-62.

https://doi.org/10.5209/CIYC.52944

Comisión Europea (2016). Special Eurobarometer 452 - October 2016. Media pluralism and democracy. Bruselas: Unión Europea. ISBN: 9789279632013

https://ec.europa.eu/information_society/newsroom/image/document/2016-47/sp452-summary_en_19666.pdf

Consejo de Europa (2009). How member states ensure the legal, financial, technical and other appropriate conditions required to enable public service media to discharge their remit. Estrasburgo: Consejo de Europa.

https://rm.coe.int/CoERMPublicCommonSearchServices/DisplayDCTMContent?document/d=0900001680483b19

Downey, John; Stanyer, James (2010). “Comparative media analysis: Why some fuzzy thinking may help. Applying fuzzy set qualitative comparative analysis to the personalization of mediated political communication". European journal of communication, v. 25, n. 4, pp. 331-347.

https://doi.org/10.1177/0267323110384256

Downey, John; Stanyer, James (2013). “Exposing politicians' peccadilloes in comparative context: Explaining the frequency of political sex scandals in eight democracies using fuzzy set qualitative comparative analysis". Political communication, v. 30, n. 3, pp. 495-509.

https://doi.org/10.1080/10584609.2012.737434

EAO (2016). Yearbook. Television, VOD, cinema and video in 40 European States: markets and players, services and usage. http://yearbook.obs.coe.int

Eurodata (2016). One TV year in the world. Eurodata TV Worldwide.

https://www.glance-mediametrie.com/en/one-television-year-world-0

Fernández-Quijada, David; Masip, Pere (2013). "Tres décadas de investigación española en comunicación: hacia la mayoría de edad". Comunicar, v. 21, n. 41, pp. 15-24.

https://doi.org/10.3916/C41-2013-01 
Gaitán-Moya, Juan-Antonio; Caffarel-Serra, Carmen; Lozano-Ascencio, Carlos; Piñuel-Raigada, José-Luis (2018). “Condiciones y rendimientos de la Investigacion en Comunicacion: la vision de los academicos". CIC. Cuadernos de información y comunicación, v. 23, pp. 106-123.

https://doi.org/10.5209/CIYC.60910

García-Cascales, María-Socorro; Lamata, María-Teresa (2012). "On rank reversal and Topsis method". Mathematical and computer modelling, v. 56, n. 5-6, pp. 123-132.

https://doi.org/10.1016/j.mcm.2011.12.022

González, Miguel (2019). "Vox ya no pide cerrar las televisiones autonómicas sino privatizarlas". El país, 21 mayo. https://elpais.com/politica/2019/05/20/actualidad/1558374996_861017.html

Goyanes, Manuel (2017). Desafío a la investigación estándar en comunicación. Críticas y alternativas. Barcelona: UOC. ISBN: 9788491166757

Goyanes, Manuel; Rodríguez-Gómez, Eduardo-Francisco; Rosique-Cedillo, Gloria (2018). “Investigación en comunicación en revistas científicas en España (2005-2015): de disquisiciones teóricas a investigación basada en evidencias". El profesional de la información, v. 27, n. 6, pp. 1281-1291.

https://doi.org/10.3145/epi.2018.nov.11

Hallin, Daniel C.; Mancini, Paolo (2004). Comparing media systems. Three models of media and politics. Cambridge: Cambridge University Press. ISBN: 9780521543088

Harrison, Ellie; Wood, Vincent (2020). “Tony Hall: BBC faces 'torrid' time after director general's departure, senior figures warn". Independent, 20 January.

https://www.independent.co.uk/arts-entertainment/tv/news/tony-hall-bbc-director-general-quit-resignreplacement-a9291706.html

Hwang, Ching-Lai; Yoon, Kwangsun (1981). Multiple attribute decision making. Methods and applications. A state-ofthe-art survey. New York: Springer-Verlag. ISBN: 9783642483189

Inhoffen, Lisa (2018). "Mehrheit wünscht sich Abstimmung über Rundfunkbeitrag”. YouGov, 6 März. https://yougov.de/news/2018/03/06/mehrheit-wunscht-sich-abstimmung-uber-rundfunkbeit

Lamata, María-Teresa; Liern, Vicente; Pérez-Gladish, Blanca (2016). “Doing good by doing well: A MCDM framework for evaluating corporate social responsibility attractiveness". Annals of operations research, v. 267, pp. 249-266.

https://doi.org/10.1007/s10479-016-2271-8

López-Rabadán, Pablo; Vicente-Mariño, Miguel (2011). “Métodos y técnicas de investigación dominantes en las revistas científicas españolas sobre comunicación” (2000- 2009). En: Piñuel-Raigada, José-Luis; Lozano-Ascencio, Carlos; García-Jiménez, Antonio (eds.). Investigar la comunicación en España. Actas del $1^{\text {er }}$ Simposio nacional de grupos consolidados de investigación en comunicación y 1er Congreso nacional de metodología de la investigación en comunicación. Facultad de Ciencias de la Comunicación. Fuenlabrada: Universidad Rey Juan Carlos, pp. 665-679. ISBN: 9788469427132

Lowe, Gregory-Ferrell; Berg, Christian E. (2013). "The funding of public service media: A matter of value and values". International journal on media management, v. 15, n. 2, pp. 77-97.

https://doi.org/10.1080/14241277.2012.748663

Lowe, Gregory-Ferrell; Maijanen, Päivi (2019). "Making sense of the public service mission in media: youth audiences, competition, and strategic management". Journal of media business studies, v. 16, n. 1, pp. 1-18.

https://doi.org/10.1080/16522354.2018.1553279

Martínez-Nicolás, Manuel; Saperas-Lapiedra, Enric (2016). “Objetos de estudio y orientación metodológica de la reciente investigación sobre comunicación en España (2008-2014)”. Revista latina de comunicación social, v. 71, pp. 1.3651.384.

https://doi.org/10.4185/RLCS-2016-1150es

Mendel, Toby (2011). Public service broadcasting: a comparative legal survey. Paris: Unesco. ISBN: 9789231042041 https://unesdoc.unesco.org/ark:/48223/pf0000192459

Miguel-De-Bustos, Juan-Carlos; Izquierdo-Castillo, Jessica (2019). “¿Quién controlará la comunicación? El impacto de los Gafam sobre las industrias mediáticas en el entorno de la economía digital”. Revista latina de comunicación social, v. 74, pp. 803-821.

https://doi.org/10.4185/RLCS-2019-1358

Mombelli, Armando (2018). “'No Billag': qué es y qué repercusiones tendría la iniciativa”. Swiss/nfo, 30 enero. https://www.swissinfo.ch/spa/olítica/iniciativa-popular_-no-billag---qu\%C3\%A9-es-y-qu\%C3\%A9-repercusionestendr\%C3\%Ada-la-iniciativa/43860578 
Nardo, Michela; Saisana, Michaela; Saltelli, Andrea; Tarantola, Stefano (2005). Tools for composite indicators building. European Commission, report EUR 21682 EN (Joint Research Centre, Ispra, Italy).

Nelson, Jacob L.; Lei, Ryan F. (2018). "The effect of digital platforms on news audience behavior". Digital journalism, v. 6, n. 5, pp. 619-633.

https://doi.org/10.1080/21670811.2017.1394202

Norris, Pippa (2009). “Comparative political communications: Common frameworks or Babelian confusion?". Government and opposition, v. 44, n. 3, pp. 321-340.

https://doi.org/10.1111/j.1477-7053.2009.01290.x

OECD/JRC (2008). Handbook on constructing composite indicators. Methodology and user guide. Paris: OECD Publisher. ISBN: 9789264043459

https://www.oecd.org/sdd/42495745.pdf

Ofcom (2019). Ofcom's annual report on the BBC.

https://www.ofcom.org.uk/_data/assets/pdf_file/0026/173735/second-bbc-annual-report.pdf

Public Media Alliance (2019). Changing times for public media funding, 9 August.

https://www.publicmediaalliance.org/changing-times-for-public-media-funding

Raats, Tim; Pauwels, Caroline (2011). "In search of the Holy Grail? Comparative analysis in public broadcasting research". In: Donders, Karen; Moe, Hallvard. Exporting the public value test. The regulation of public broadcasters' new media services across Europe. Göteborg: Nordicom, pp. 17-28. ISBN: 9789186523268

https://www.nordicom.gu.se/sv/system/tdf/publikationer-hela-pdf/exporting_the_public_value.pdf?file=1

Ramsey, Phil (2018). "Ireland: In search of reform for public service media funding". In: Herzog, Christian; Hilker, Heiko; Novy, Leonard; Torun, Orkan. Transparency and funding of public service media: Deutsche Debatte im internationalen Kontex. Wiesbaden: Springer VS, pp. 77-90. ISBN: 9783658179977

Ramsey, Phil; Herzog, Christian (2018). "The end of the television licence fee? Applying the German household levy model to the United Kingdom". European journal of communication, v. 33, n. 4, pp. 430-444.

https://doi.org/10.1177/0267323118775300

Rantanen, Terhi (2013). "A critique of the systems approaches in comparative media research: A Central and Eastern European perspective". Global media and communication, v. 9, n. 3, pp. 257-277.

https://doi.org/10.1177/1742766513504175

Repiso, Rafael; Delgado-López-Cózar, Emilio; Torres-Salinas, Daniel (2011). “Análisis bibliométrico y de redes sociales en tesis doctorales españolas sobre televisión (1976/2007)". Comunicar, v. 19, n. 37, pp. 151-159.

https://doi.org/10.3916/C37-2011-03-07

Rodríguez-Vázquez, Ana-Isabel; Direito-Rebollal, Sabela (2018). “Hacia el Total View y la medición integrada: la televisión pública y su conexión con la audiencia”. En: López-Golán, Mónica; Campos-Freire, Francisco; López-López, Paulo C.; Rivas-Echeverría, Francklin. La comunicación en la nueva sociedad digital. Mérica, Venezuela: PUCE-UTPL, pp. $245-258$. ISBN: 9789801119326

Rotermund, Hermann (2018). "Digital media culture and public service media in the platform era”. In: Lowe, GregoryFerrell; Van-den-Bulck, Hilde; Donders, Karen. Public service media in the networked society. Göteborg: Nordicom, pp. 75-89. ISBN: 9789187957734

https://www.nordicom.gu.se/en/publikationer/public-service-media-networked-society

Saisana, Michaela; Tarantola, Stefano (2002). State-of-the-art report on current methodologies and practices for composite indicator development. EUR 20408 EN, European Commission-JRC: Italy.

Saltelli, Andrea (2007). "Composite indicators between analysis and advocacy". Social indicators research, v. 81, pp. 65-77. https://doi.org/10.1007/s11205-006-0024-9

Saurwein, Florian; Eberwein, Tobias; Karmasin, Matthias (2019). “Public service media in Europe: Exploring the relationship between funding and audience performance". Javnost, v. 26, n. 3, pp. 291-308.

https://doi.org/10.1080/13183222.2019.1602812

Schulz, Anne; Levy, David; Nielsen, Rasmus-Kleis (2019). Old, educated, and politically diverse: The audience of public service news. Oxford: Reuters Institute for the Study of Journalism. ISBN: 9781907384646

https://reutersinstitute.politics.ox.ac.uk/sites/default/files/2019-09/The_audience_of_public_service_news_FINAL.pdf

The economist (2017). Democracy index 2016. Revenge of the "deplorables". London, New York \& Hong Kong: The Economist Intelligence Unit.

http://felipesahagun.es/wp-content/uploads/2017/01/Democracy-Index-2016.pdf

https://www.transparency.org.nz/docs/2017/Democracy_Index_2016.pdf 
Transparency International (2017). Corruption perceptions index 2016.

https://www.transparency.org/news/feature/corruption_perceptions_index_2016

Trappel, Josef (2016). "Taking the public service remit forward across the digital boundary". International journal of digital television, v. 7, n. 3, pp. 273-295.

https://doi.org/10.1386/jdtv.7.3.273_1

Túñez-López, Miguel; Martínez-Solana, Yolanda; Valarezo-González, Karina (2014): “Análisis de productividad, impacto e índice h de la investigación en Comunicación a través de los perfiles personales en Google Académico". Revista latina de comunicación social, v. 69, pp. 684-709.

https://doi.org/10.4185/RLCS-2014-1030

Warner, Mervyn (2019). Funding public media. An insight into contemporary funding models. Public Media Alliance. https://www.publicmediaalliance.org/wp-content/uploads/2017/08/Funding-Public-Media-.pdf

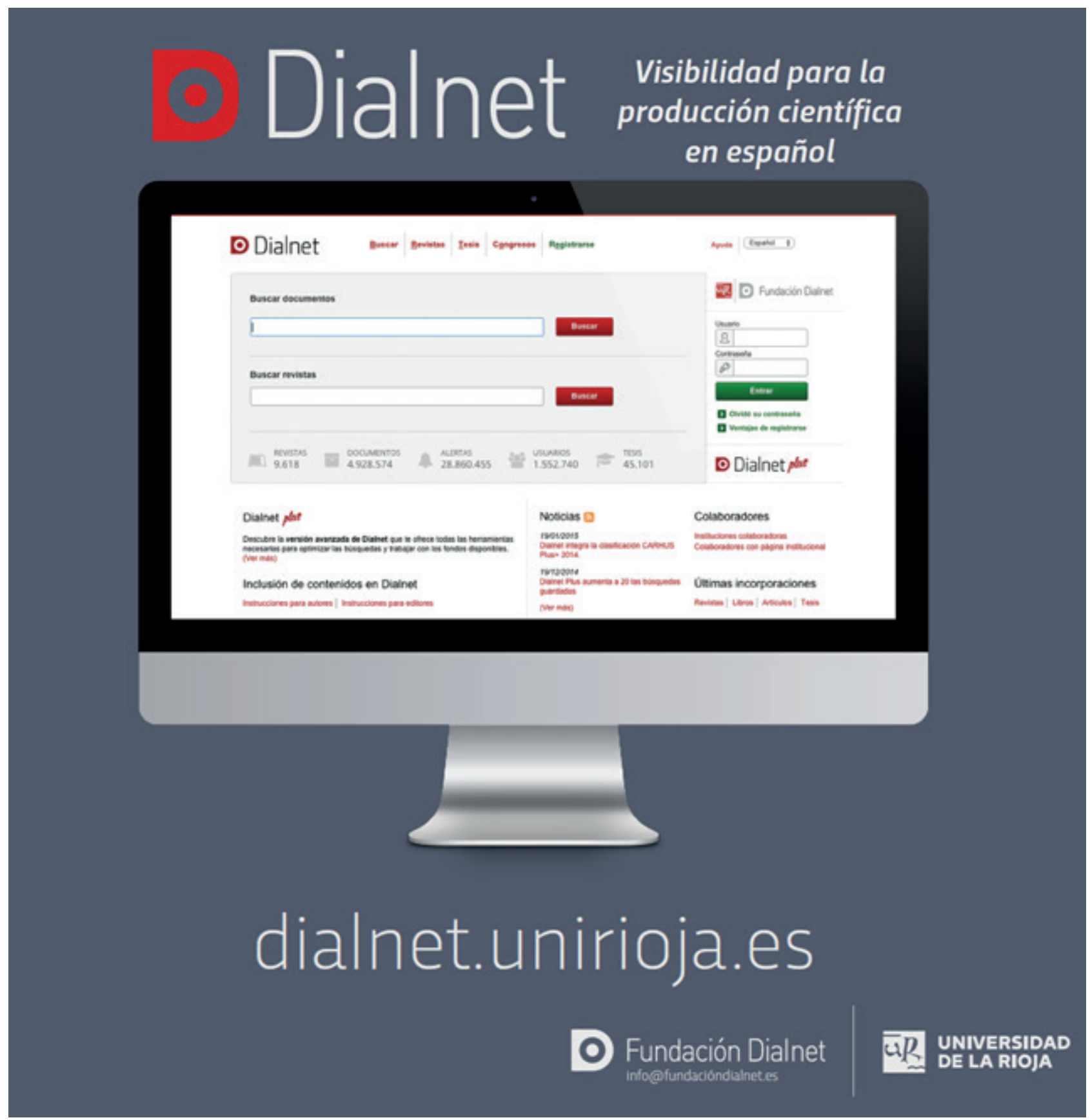

